\title{
COMMENTS
}

\section{An Attempt to Intervene in the Confusion: Standing Requirements for Rule 24 Intervenors}

\author{
Amy M. Gardner $\dagger$
}

Suppose you live near a minimum-security, short-term facility used by the Immigration and Naturalization Service to house aliens awaiting processing, exclusion, or asylum. ${ }^{1}$ You discover that, contrary to representations by government officials, many of your "neighbors" are convicted felons who have completed jail sentences in the United States and are awaiting a determination of their alien status. A group of these aliens then start a riot in which forty escape from the facility. You fear that more convicted felons might escape into your neighborhood.

You then learn that an elected official is suing the Department of Justice over the situation. You later discover, though, that much of his suit centers not around the danger to innocent citizens, but on a political matter. In addition, given the problems encountered by other members of Congress in trying to gain standing to sue in similar cases, ${ }^{2}$ you are concerned that the case will not get into court on the strength of the official's stake alone. As a result, you, along with some other homeowners, try to intervene in the suit. Your application to intervene meets the requirements for permissive intervention under Federal

$\dagger$ B.A. 1997, Luther College; J.D. Candidate 2002, The University of Chicago.

1 This example is based on the facts of Chiles $v$ Thornburgh, 865 F2d 1197 (11th Cir 1989). For further discussion of the case, see notes $82-87$ and accompanying text. The Eleventh Circuit held that Senator Chiles did not have standing to bring the suit, and the governor of Florida did not have standing to intervene. Chiles, $865 \mathrm{~F} 2 \mathrm{~d}$ at 1216 . It also found that the district court did not abuse its discretion in denying the intervention attempts by a local homeowners association and individual homeowners living near the facility. Id. The court did, however, allow intervention by Dade County due to the economic burdens that the county was forced to undertake because of the riots and escapes related to the facility. Id at 1209.

2 See, for example, Coleman v Miller, 307 US 433, 438, 446 (1939) (finding that legislators have an "adequate interest in maintaining the effectiveness of their votes" but declining to address the merits of the suit on the grounds that it was a political question). See also Bowsher $v$ Synar, 478 US 714, 721 (1986) (declining to address congressional standing). 
Rule of Civil Procedure $24,{ }^{3}$ but the district court refuses to allow your party to intervene, stating that you do not meet the Article III standing requirements. ${ }^{4}$

How can it be that the court does not have jurisdiction over your interests in the suit when they appear so clear? And as long as you meet the requirements for intervention set forth by the Federal Rules of Civil Procedure, how can there be additional requirements when Rule 24 does not even refer to them? To add insult to injury, you discover that any appeal may not help your cause, because trial courts have broad discretion in determining whether to allow permissive intervention. ${ }^{5}$ Finally, had the case originally been brought in a different circuit, you might have been permitted to intervene. ${ }^{6}$

\section{Rule 24 states in relevant part:}

(a) Intervention of Right. Upon timely application anyone shall be permitted to intervene in an action: (1) when a statute of the United States confers an unconditional right to intervene; or (2) when the applicant claims an interest relating to the property or transaction which is the subject of the action and the applicant is so situated that the disposition of the action may as a practical matter impair or impede the applicant's ability to protect that interest, unless the applicant's interest is adequately represented by existing parties.

(b) Permissive Intervention. Upon timely application anyone may be permitted to intervene in an action: (1) when a statute of the United States confers a conditional right to intervene; or (2) when an applicant's claim or defense and the main action have a question of law or fact in common. When a party to an action relies for ground of claim or defense upon any statute or executive order administered by a federal or state governmental officer or agency or upon any regulation, order, requirement or agreement issued or made pursuant to the statute or executive order, the officer or agency upon timely application may be permitted to intervene in the action. In exercising its discretion the court shall consider whether the intervention will unduly delay or prejudice the adjudication of the rights of the original parties.

\section{US Const Art III, $\$ 2, \mathrm{cl} 1$ states:}

The judicial Power shall extend to all Cases, in Law and Equity, arising under this Constitution, the Laws of the United States, and Treaties made, or which shall be made, under their Authority;-to all Cases affecting Ambassadors, other public Ministers and Consuls; - to all Cases of admiralty and maritime Jurisdiction; - to Controversies to which the United States shall be a Party; - to Controversies between two or more States;-between a State and Citizens of another State;-between Citizens of different States,-between Citizens of the same State claiming Lands under Grants of different States, and between a State, or the Citizens thereof, and foreign States, Citizens or Subjects.

For further discussion of Article III standing, see Part I.A.

5 See Brotherhood of Railroad Trainmen v Baltimore \& Ohio Railroad, 331 US 519, 524 (1947) ("[I]n the absence of an abuse of discretion, no appeal lies from an order denying leave to intervene where intervention is a permissive matter within the discretion of the court."); United States Postal Service v Brennan, 579 F2d 188, 191 (2d Cir 1978) ("Permissive intervention is wholly discretionary with the trial court. ... [The trial court's discretion] may only be disturbed for clear abuse of discretion.... [I]ndeed, we have not found a single case in which a denial of permissive intervention under Rule 24(b) was reversed solely for an abuse of discretion.") (citation omitted); Afro-American Patrolmen's League v Duck, 503 F2d 294, 298 (6th Cir 1974) ("Intervention under Rule 24(b) is addressed to the sound discretion of the trial court.").

6 See Part II.B for a discussion of the circuit split that causes this result. 
As the example above demonstrates, defining the requirements for parties to intervene under Federal Rule of Civil Procedure 24 is critically important. While much has been said about intervention of right under Rule $24(\mathrm{a}){ }^{7}$, the rights of those trying to intervene in the category of "permissive intervention" under Rule 24(b) have not received as much attention. Rule 24, along with Article III of the Constitution, sets forth requirements for standing, but Rule 24(b)(2) "does not specify any particular interest that will suffice for permissive intervention and, as the Supreme Court has said, it 'plainly dispenses with any requirement that the intervenor ... have a direct personal or pecuniary interest in the subject of the litigation."' The lower courts, however, have been unable to agree as to how this should be interpreted and implemented. ${ }^{10}$

Courts have explained the requirements for permissive intervention by stating: "Given that an application is timely, the Court in its discretion may permit intervention under Rule 24(b)(2) if the applicant presents a 'claim or defense' which has 'a question of law or fact in common' with the main action." While some courts have described the permissive intervention standard as "liberal," scholars have gone so far as to state that an intervenor-by-permission need not "have been a proper party at the beginning of the suit, since of the two tests for permissive joinder of parties, a common question of law or fact and some right to relief arising from the same transaction, only the first is stated as a limitation on intervention."

7 See, for example, Erik Figlio, Stacking the Deck against "Purely Economic Interests": Inequality and Intervention in Environmental Litigation, $35 \mathrm{Ga}$ L Rev 1219 (2001) (addressing intervention of right in suits under the National Environmental Policy Act); Ellyn J. Bullock, Note, Acid Rain Falls on the Just and the Unjust: Why Standing's Criteria Should Not Be Incorporated into Intervention of Right, $1990 \mathrm{U}$ Ill L Rev 605, 610 (arguing that standing should be disentangled from intervention to allow intervention of right in environmental claims); Cindy Vreland, Comment, Public Interest Groups, Public Law Litigation and Federal Rule 24(a), 57 U Chi L Rev 279, 281 (1990) (arguing that courts should weigh the interests behind Rule 24(a) differently when a public interest group seeks to intervene in a public law case); Rodrick J. Coffey, Note, Giving a Hoot about an Owl Does Not Satisfy the Interest Requirement for Intervention: The Misapplication of Intervention as of Right in Coalition of Arizona/New Mexico Counties for Stable Economic Growth v. Department of Interior, 1998 BYU L Rev 811,812 (arguing that “Article III standing is the appropriate standard for determining whether a potential intervenor has sufficient interest in the pending litigation to intervene as of right").

8 See note 4.

9 Charles Alan Wright, Arthur R. Miller, and Mary Kay Kane, 7C Federal Practice and Procedure $\$ 1911$ at 356 (West 1986), quoting SEC v US Realty \& Improvement Co, 310 US 434, 459 (1940). Despite this apparently helpful explanation of requirements for intervenors, the current split among circuits and commentators demonstrates that the requirements are not so plain after all.

10 See Part II.A.

11 Usery v Brandel, 87 FRD 670,677 (W D Mich 1980), quoting FRCP 24(b)(2).

12 Usery, 87 FRD at 677.

13 Wright, Miller, and Kane, 7C Federal Practice and Procedure $\$ 1911$ at 357 (cited in note 
Nevertheless, actual applications of the rule by some courts do not reflect this supposed liberal spirit and the accompanying low threshold. Three different views have been adopted by the various circuits: (1) a separate showing of Article III standing is not required for intervention under Rule 24; (2) a separate showing of the Article III standing requirements must be made; or (3) an Article III inquiry is not necessary because the Rule 24 requirements actually require a higher threshold than does Article III.

The Supreme Court has held that intervenors by right or by permission ordinarily have the right to appeal an adverse final judgment by a trial court, just as parties with standing do. ${ }^{14}$ Despite the obvious argument that, if the intervenors can appeal on their own, they certainly should be able to join a suit in which the main parties meet the requirements for standing, the area of intervention is mired in a circuit split. Part I of this Comment will provide background on standing doctrine, the history and policy goals of permissive intervention, the jurisdictional basis for permissive intervention, and Supreme Court jurisprudence in this area. Part II will address the three trends among the lower court rulings and examine the bases relied upon in these court decisions. Part III will focus on the problems resulting from, and hence the importance of resolving, the circuit split. In Part IV, this Comment will suggest the solution that seems most consistent with Rule 24 and Article III: although an amendment to the Rule making clear that permissive intervention does not require an additional Article III showing would be optimal, courts should permit the party seeking to intervene to do so, provided that (1) the requirements to intervene under Rule 24 are met, and (2) the original parties remain in the suit and meet the requirements for standing.

\section{BACKGROUND ON STANDING DOCTRINE AND PERMISSIVE INTERVENTION}

\section{A. Standing Doctrine}

Although "[t]raditionally, standing was required only of parties seeking to initiate a lawsuit," importance of determining whether the court has jurisdiction to hear a case is clear: "Without jurisdiction the court cannot proceed in any cause. Jurisdiction is power to declare the law, and when it ceases to exist, the only function remaining to the court is that of announcing

9) (citation omitted).

14 Stringfellow v Concerned Neighbors in Action, 480 US 370, 375-76 (1987) ("An intervenor, whether by right or by permission, normally has the right to appeal an adverse final judgment by a trial court.").

15 Ruiz v Estelle, 161 F3d 814, 830 (5th Cir 1998). 
the fact and dismissing the cause." ${ }^{16}$ In order for the court to have jurisdiction over the claim, the parties must have standing.

The Supreme Court has said that standing "does not refer simply to a party's capacity to appear in court. Rather, standing is gauged by the specific common-law, statutory, or constitutional claims that a party presents." " Generally, two types of standing must be established: Article III standing and prudential standing that meets the requirements of the particular piece of legislation at issue. ${ }^{28}$

Article III, $\S 2$ of the Constitution establishes federal court jurisdiction, but limits it to "Cases" and "Controversies," leaving it up to the Congress whether to establish inferior courts and to determine their jurisdiction within Article III's framework. ${ }^{20}$ As the Supreme Court explained in Lujan $v$ Defenders of Wildlife, ${ }^{21}$ the three elements of standing are:

(1) an "injury in fact" that is "concrete and particularized" and "actual or imminent";

(2) a causal relationship between the injury and the conduct complained of; and

(3) 'it must be 'likely,' as opposed to merely 'speculative,' that the injury will be 'redressed by a favorable decision.","

In addition, if the plaintiff cannot claim an injury greater than one sustained as a member of the general public, she cannot meet the distinct and palpable injury requirement of the Lujan test. ${ }^{23}$ Moreover, if Congress has not explicitly acted to create standing through statutory enactment, the plaintiff must also "overcome ... the judiciary's use of standing as a tool of judicial self-restraint.",

16 Ex Parte McCardle, 74 US (7 Wall) 506, 514 (1868).

17 International Primate Protection League $v$ Administrators of Tulane Educational Fund, 500 US 72, 77 (1991) (finding standing for organizations and individuals seeking to protect and obtain custody of three monkeys used for medical experiments).

18 Commentators have explained standing as "a question of substantive law, answerable by reference to the statutory and constitutional provision whose protection is invoked." William A. Fletcher, The Structure of Standing, 98 Yale L J 221, 229 (1988).

19 See note 4 for the text of US Const Art III, $\$ 2, \mathrm{cl} 1$.

20 Sheldon $v$ Sill, 49 US $441,448,449$ (1850) ("Congress, having the power to establish [the lower federal] courts, must define their respective jurisdictions... Congress may withhold from any court of its creation jurisdiction of any of the enumerated controversies.").

21504 US 555 (1992).

22 Id at 560-61 (internal citations omitted).

23 John E. Nowak and Ronald D. Rotunda, Constitutional Law $\$ 2.12$ at 77 (West 5th ed 1995) ("Congress can always create standing by conferring a cash bounty on the victorious plaintiff. That would assure that plaintiff's relief gives him tangible benefit not available to the public at large."). 
If Congress has acted, then in addition to meeting Article III's requirements, a plaintiff may have to satisfy several prudential principles in order to have her claim heard. ${ }^{25}$ For example, generally she must assert her own rights and not the rights of third parties, she must be within the zone of interests ${ }^{26}$ protected by the provisions at issue, and she cannot raise abstract questions of wide public significance that amount to "generalized grievance[s]" and are considered best left to the representative branches. ${ }^{27}$ However, courts frequently assert that "when the constitutional requisites are met, the basic practical and prudential concerns underlying the standing doctrine are generally satisfied." ${ }^{2 s}$ It should also be noted that the Court has held that Congress cannot expand jurisdiction beyond Article III through statutory means.

Applying standing principles to parties seeking to intervene is where the analysis becomes more difficult. Courts may deny would-be intervenors Article III standing on the basis that their injuries are not particularized enough ${ }^{30}$ or that the grievance would not be remedied by the court."

While Article III provides the general framework for analyzing standing, and prudential concerns must be considered, this Comment argues that once the plaintiffs in a suit meet the Article III requirements, analysis of the issue of standing for intervenors should extend

25 Charles Alan Wright, Arthur R. Miller, and Mary Kay Kane, 13 Federal Practice and Procedure $\$ 3536$ at 347 (West 2d ed 1986) ("Once this [Article III] threshold hás been crossed, a variety of prudential limits may be imposed.").

26 See, for example, Nowak and Rotunda, Constitutional Law $\$ 2.12$ at 78 (cited in note 23) (" $[T]$ he question is whether the entire statutory scheme (not merely the statute under which plaintiffs have sued) evidences an intent to preclude judicial review at the plaintiff's request.").

27 Chiles v Thornburgh, 865 F2d 1197, 1205 (11th Cir 1989). For further discussion of this case, see Part II.B.1.

28 Duke Power Co v Carolina Environmental Study Group, Inc, 438 US 59, 81 (1978).

29 Seminole Tribe of Florida v Florida, 517 US 44, 73 (1996) ("Article I cannot be used to circumvent the constitutional limits placed upon federal jurisdiction."); Gladstone, Realtors $v$ Village of Bellwood, 441 US 91, 100 (1979):

Congress may, by legislation, expand standing to the full extent permitted by Art. III, thus permitting litigation by one who otherwise would be barred by prudential standing rules. In no event, however, may Congress abrogate the Art. III minima: A plaintiff suffered "a distinct and palpable injury to himself" that is likely to be redressed if the requested relief is granted.

30 See, for example, Palila $v$ Hawaii Department of Land and Natural Resources, 2000 US App LEXIS 33704, *2 (9th Cir) (holding that an intervenor did not have standing due to failure to demonstrate a concrete, particularized injury should the Palila, an endangered bird, become extinct).

31 See, for example, United States v Oregon, 122 FRD 571, 579 (D Or 1988) (denying permissive intervention because of delay and because the would-be intervenors had not shown that, even if they were successful in their suit to be considered in a renegotiation of the Columbia River Fish Management Plan, a renegotiated plan would be more favorable to their interests). 
beyond a cursory reading of the text of the Article to include the historical and policy goals of permissive intervention.

\section{B. The History and Policy Goals of Permissive Intervention}

Intervention originated in the equity motion allowing a nonparty with a superior claim to property held by a sequestrator or receiver to claim his interest. ${ }^{32}$ In United States courts, the practice was adapted to allow multi-party disputes lacking complete diversity of citizenship to proceed with all parties. ${ }^{33}$

Today, intervention is frequently relied upon by groups attempting to protect the public interest. Examples include state governments trying to intervene in actions brought by the United States, ${ }^{34}$ governmental entities intervening in private litigation, ${ }^{35}$ organizations seeking to intervene in cases that potentially affect their members or objectives, ${ }^{35}$ and individuals trying to protect what they feel is in the public interest. ${ }^{37}$

Without the option of intervention, these interests might never be heard in court as part of a particular case because the parties to the original suit represent different interests. Instead, the parties who wish to intervene would be faced with three options: sit back and watch as the court makes a determination without hearing their side, and then try to file a separate suit to disrupt the judgment in the original action; try to sway the political system; or give up without having their voices heard. As a result, these pressures have meant that the doctrine of permissive intervention has been "justified by ... [the goal of avoiding] injustice." ${ }^{38}$

32 Geoffrey C. Hazard, Jr., Colin C. Tait, and William A. Fletcher, Pleading and Procedure: State and Federal Cases and Materials 753-54 (Foundation 8th ed 1999).

33 Id.

34 See, for example, Cascade Natural Gas Corp v El Paso Natural Gas Co, 386 US 129, 13536 (1987) (upholding intervention by the state of California on the grounds that its interests were inadequately represented in an antitrust suit involving companies doing business in California).

35 Many cases, for example, uphold the right of a government to intervene when the constitutionality of one of its laws is at issue. See, for example, Ameron, Inc v United States Army Corps of Engineers, $787 \mathrm{~F} 2 \mathrm{~d} 875,888$ (3d Cir 1986) (upholding the right of Congress to intervene in defense of a federal statute being challenged as unconstitutional); County of San Bernardino $v$ Harsh California Corp, 52 Cal 2d 341,340 P2d 617,621 (1959) (upholding the right of the federal government to intervene in a suit in state court over the proper interpretation of a federal statute).

36 See, for example, Sagebrush Rebellion, Inc v Watt, 713 F2d 525, 528-29 (9th Cir 1983) (allowing a conservation group to intervene in a suit against the Secretary of the Interior).

37 See, for example, Jane L. McClellan, Comment, Stopping the Rush to the Death House: Third-Party Standing in Death-Row Volunteer Cases, 26 Ariz St L J 201, 228-31 (1994) (discussing "next friend" standing for family members of prisoners on death row).

38 Note, Intervention in Federal Equity Cases, 31 Colum L Rev 1312, 1312 (1931). See note 111 and accompanying text discussing cases in which alleged injustices can be remedied only by FRCP 24(b). 
Rule 24(b) has not been amended since it was adopted in $1938 .^{39}$ However, an amendment to Rule 24(a) (intervention as of right) indicates the intent and spirit of the Rules. When FRCP 24(a) was amended in 1966, the Advisory Committee, rather than making intervention as of right more difficult, removed a 1948 requirement that the applicant trying to intervene "is or may be bound by a judgment in the action." ${ }^{, 40}$ The Advisory Committee Notes state that the requirement was stricken because it could "defeat intervention in some meritorious cases." $"$ a1

The Second Circuit has characterized the 1966 changes to Rule 24(a) as a reflection of the attitude toward intervenors in general: "The policy of liberalizing the right to intervene in federal actions is reflected in the change of language of Rule 24(a) in 1966." ${ }^{42}$ Thus, the Advisory Committee Notes regarding intervention under Rule 24(a) reflect a liberal spirit that would seem to favor minimizing the requirements placed on parties seeking to intervene. When considering permissive intervention, the 1966 amendment and accompanying Advisory Committee Notes seem to weigh in favor of allowing intervention in more meritorious cases, rather than fewer. ${ }^{43}$

\section{Jurisdictional Basis for Permissive Intervention}

The issue of standing for intervenors has not always received its current treatment. Some earlier cases addressed the issue of standing

39 Wright, Miller, and Kane, 7C Federal Practice and Procedure $\S 1910$ at 354-55 (cited in note 9).

40 The pre-1966 version of Rule 24(a) stated:

Upon timely application anyone shall be permitted to intervene in an action: (1) when a statute of the United States confers an unconditional right to intervene; or (2) when the representation of the applicant's interest by existing parties is or may be inadequate and the applicant is or may be bound by a judgment in the action; or (3) when the applicant is so situated as to be adversely affected by a distribution or other disposition of property which is in the custody or subject to the control or disposition of the court or an officer thereof.

FRCP 24(a) (1948), reprinted in Moore's Federal Rules and Official Forms 143 (Matthew Bender 1956). The 1966 amendments removed the second and third categories listed above and added a new category. See note 3 for the current text of the rule.

41 FRCP 24, Advisory Committee Note to the 1966 Amendments.

42 United States Postal Service v Brennan, 579 F2d 188, 193 (2d Cir 1978) (Oakes dissenting) ("The prior text of Rule 24 spoke in terms of whether representation by existing parties is or may be inadequate.' The present rule provides for intervention 'unless the applicant's interest is adequately represented by existing parties."'), quoting Nuesse v Camp, 385 F2d 694, 702 (DC Cir 1967).

43 It is true that the Advisory Committee's choice not to amend FRCP 24(b) might indicate that it did not intend this liberal spirit to apply to permissive intervention. Absent any sort of explicit statement on permissive intervention from the Advisory Committee since 1938 and absent any indication that an amendment of FRCP 24(b) was considered but rejected, analogizing from the Advisory Committee's actions and statements regarding FRCP 24(a) seems to be the only way to incorporate the Committee's intent in an analysis of permissive intervention. 
for intervenors in the language of ancillary jurisdiction. ${ }^{44}$ Since those cases, however, the practices of pendent jurisdiction ${ }^{45}$ and ancillary jurisdiction have been codified as supplemental jurisdiction in 28 USC $\S 1367(\mathrm{a}) .^{45}$ In addition to establishing supplemental jurisdiction, section 1367 establishes that, even where the district court has original jurisdiction over the suit,

[it] shall not have supplemental jurisdiction ... over claims by plaintiffs against persons made parties under [Rule 24] . . or over claims by persons ... seeking to intervene as plaintiffs under Rule 24 ... when exercising supplemental jurisdiction over such claims would be inconsistent with the jurisdictional requirements of section 1332."

Many earlier cases decided under the doctrine of ancillary jurisdiction held that ancillary jurisdiction alone did not supply "the independent jurisdictional grounds required for permissive intervention."."4 However, according to the district court in Usery $v$ Brandel $^{49}$

the same authorities state with equal certainty that no independent jurisdictional basis is necessary for intervention as of right. Rule 24(a), however, [cannot expand the courts' jurisdiction]. Intervention under section (a) is permitted without consideration of jurisdiction only because, due to the demanding standard for

44 "[A]ncillary jurisdiction [is a] court's jurisdiction to adjudicate claims and proceedings that arise out of a claim that is properly before the court.... The concept of ancillary jurisdiction has now been codified, along with the concept of pendent jurisdiction, in the supplementaljurisdiction statute." Black's Law Dictionary 855 (West 7th ed 1999). The supplemental jurisdiction statute is 28 USC $\$ 1367$ (1994). See notes $45-46$ and accompanying text.

45 Pendent jurisdiction was "a court's jurisdiction to hear and determine a claim over which it would not otherwise have jurisdiction, because the claim arises from the same transaction or occurrence as another claim that is properly before the court." Black's Law Dictionary at 856-57 (cited in note 44).

46 The most relevant part of 28 USC $\$ 1367$ (a) states:

[Aside from a few exceptions,] in any civil action of which the district courts have original jurisdiction, the district courts shall have supplemental jurisdiction over all other claims that are so related to claims in the action within such original jurisdiction that they form part of the same case or controversy under Article III of the United States Constitution. Such supplemental jurisdiction shall include claims that involve the joinder or intervention of additional parties.

4728 USC $\S 1367(b)$. The jurisdiction requirements of $\S 1332$ include diversity of citizenship among the parties and the amount in controversy requirement of seventy-five thousand dollars. 28 USC $\$ 1332$ (a) (1994 \& Supp 1998).

48 Usery, 87 FRD 670, 681 (W D Mich 1980). In support of the proposition, Usery cites Blake v Pallan, 554 F2d 947, 956-57 (9th Cir 1977); Warren G. Kleban Engineering Corp v Caldwell, 490 F2d 800, 802 (5th Cir 1974); Babcock \& Wilcox Co v Parsons Corp, 430 F2d 531, 540 (8th Cir 1970); James Wm. Moore, 3B Moore's Federal Practice § 24.18 at 24-177 to 24-183 (Matthew Bender 2d ed 1996); Charles Alan Wright, Law of Federal Courts $\$ 75$ at 373 (West 3d ed 1976).

4987 FRD 670 (W D Mich 1980). 
intervention as of right, ancillary jurisdiction is always present. The laxer standard of Rule 24(b)(2) [permissive intervention] ... provides no such guarantee, and applications under its terms must consequently be examined for a jurisdictional basis."

The Usery court provided for exceptions if "there is a "tight nexus' with a subject matter properly in federal court," and held that "to the extent that it is the effective basis for ancillary jurisdiction over interventions of right, ancillary jurisdiction may properly be exercised if the facts of a particular application for permissive intervention so warrant." "s1 While not holding that intervenors who meet the requirements of Rule 24 automatically have standing, the court did leave room for such an interpretation. As will be discussed below, many other decisions have adopted the same approach.

\section{ANALYSIS OF THE CIRCUIT SPLIT}

After the adoption of Rule 24(b)(2) in 1938, the Supreme Court stated that the Rule "plainly dispense[s] with any requirement that the intervenor ... have a direct personal or pecuniary interest in the subject of the litigation.."52 The Court has also held that intervenors, both by right and by permission, ordinarily have the right to appeal an adverse final judgment by a trial court, just as parties with standing do." This Comment argues that if intervenors can appeal a decision in a suit, they should be able to intervene in the suit, so long as the original parties have standing and the intervenors meet the requirements of Rule 24. Despite the fact that the Court appeared to have resolved the question by apparently discarding any separate Article III standing requirement, ${ }^{34}$ the area of intervention is mired in a circuit split. ${ }^{5 s}$

50 Id at 681 (internal citations omitted).

51 Id, quoting Revere Copper \& Brass Inc v Actua Casualty \& Surety Co, 426 F2d 709, 714 (5th Cir 1970).

52 SEC v US Realty \& Improvement Co, 310 US 434, 459 (1940).

53 Stringfellow $v$ Concerned Neighbors in Action, 480 US 370, 375-76 (1987) ("An intervenor, whether by right or by permission, normally has the right to appeal an adverse final judgment by a trial court."). See also Didrickson v United States Department of the Interior, 982 F2d 1332,1338 (9th Cir 1992):

An intervenor's standing to pursue an appeal does not hinge upon whether the intervenor could have sued the party who prevailed in the district court. To determine whether an intervenor may appeal from a decision not being appealed by one of the parties in the district court, the test is whether the intervenor's interests have been adversely affected by the judgment. Generally, an intervenor may appeal from any order adversely affecting the interests that served as the basis for intervention, provided that the requirements of Article III are satisfied.

54 US Realty, 310 US at 459 ("This provision plainly dispenses with any requirement that the intervenor shall have a direct personal or pecuniary interest in the subject of the litigation.").

55 See Part II.C for a discussion of the effects of the circuit split. 
Courts have taken three different approaches in deciding what is required of would-be permissive intervenors. ${ }^{56}$ In some instances, the same court has used multiple approaches in different cases. This Part describes the Supreme Court's holdings regarding Rule 24, the three different views to which lower courts have subscribed, and the resulting problems.

\section{A. Supreme Court Jurisprudence on Rule 24}

The Supreme Court has held that an interest under Rule 24(a)(2) means a "significantly protectable interest," but the Court has never clearly articulated how the "significantly protectable interest" requirement relates to the Article III requirements or the Rule 24(b) requirements. ${ }^{\text {s. }}$ A consideration of the Court's cases addressing intervention is helpful in attempting to understand the circuit split.

Perhaps the most relevant of the Court's recent opinions, Diamond $v$ Charles, ${ }^{57}$ is factually distinguishable from the typical intervenor cases, which concern standing in the initial suit that involves both a plaintiff and a defendant. In Diamond, an intervenor was trying to continue a suit after one of the original parties had dropped out. The Court held that Article III standing requirements had to be satisfied in addition to the requirements set forth in Rule $24^{60}$ However, the Court did not address whether the Article III requirements must be met in a case in which the original parties remain in the suit. ${ }^{61}$ Rather, as the Fifth Circuit has recognized, "The Diamond Court merely recognized that some courts have equated the Rule's interest requirement with that of standing." ${ }^{62}$ The Diamond Court recognized the confusion among the lower courts, yet declined to put forth a clear rule. ${ }^{63}$

56 The lower court holdings on the question of whether intervenors must meet Article III standing requirements can only be described as "anomalous." See, for example, Chiles v Thornburgh, 865 F2d 1197, 1212 (11th Cir 1989) (stating that lower courts have reached anomalous decisions on the issue of whether a party seeking to intervene must satisfy not only the requirements of Rule 24 but also the requirements of Article III).

57 Donaldson $v$ United States, 400 US 517, 531 (1971).

58 Chiles v Thornburgh, 865 F2d 1197, 1212 (11th Cir 1989) ("[The Supreme Court] has never articulated the precise relationship between [the interest required for intervention] and the Article III standing requirements.").

59476 US 54 (1986).

60 Id at 69 ("To continue this suit in the absence of Illinois, Diamond himself must satisfy the requirements of Art. III.").

61 Id at 68-69 ("We need not decide today whether a party seeking to intervene before a district court must satisfy not only the requirements of $24(\mathrm{a})(2)$, but also the requirements of Article III.").

62 Ruiz v Estelle, 161 F3d 814,831 (5th Cir 1998). The court continued:

Of the cases cited in Diamond, only [Southern Christian Leadership Conference $v$ Kelley, 747 F2d 777 (DC Cir 1984)] maintains that Article III (and not just Rule 24(a)(2) and 24(b)(2)) requires intervenors to possess standing. Unfortunately, the [Kelley] opinion merely assumes that Article III requires intervenors to possess standing, and offers neither 
In Trbovich $v$ United Mine Workers, ${ }^{64}$ the Supreme Court contributed to the confusion and discrepancies among the circuits because the holding seemed limited to the specific facts and statute at issue. The decision was based on the text and legislative history of Title IV of the Labor-Management Reporting and Disclosure Act, ${ }^{\text {ss }}$ which expressly limits the parties who may bring suit to set aside a union election. ${ }^{66}$ The court held that the statute imposed "no bar to intervention by a union member, so long as that intervention is limited to the claims of illegality presented by the Secretary's complaint. ${ }^{, 67}$ However, the part of the Court's opinion most relevant to this Comment focuses on claims by the Secretary of Labor that the petitioners were barred from intervening in the suit by Rule 24(a).

The Secretary had argued that he adequately represented the petitioner's interests, and thus that intervention should be barred. ${ }^{6 s}$ The Court rejected that argument, and instead found that there was "sufficient doubt about the adequacy of representation to warrant intervention." " According to the Court, "the requirement of Rule 24 is satisfied if the applicant shows that the representation of his interest 'may be' inadequate, and the burden of making that showing should be taken as minimal., ${ }^{, 00}$ Trbovich, rather than solving the issue, has been cited by courts both finding and denying standing for intervenors.

precedent nor reasons to support this assertion.

63 See Diamond, 476 US at 68:

[C]ertain public concerns may constitute an adequate 'interest' within the meaning of Federal Rule of Civil Procedure 24(a)(2).... However, the precise relationship between the interest required to satisfy the Rule and the interest required to confer standing, has led to anomalous decisions in the Courts of Appeals. We need not decide today whether a party seeking to intervene before a District Court must satisfy not only the requirements of Rule 24(a)(2), but also the requirements of Art. III.

64404 US 528 (1972).

65 Pub L No 86-257,73 Stat 534 (1959), codified at 29 USC $\$ \$ 402$ et seq (1994).

66 The statute mandated that the Secretary of Labor review the claims of union members and decide which to file as suits; the union members were prohibited from initiating the suits themselves. Id. However, the Court found that Title IV did not prevent intervention by a union member. Trbovich, 404 US at 537.

67 Id.

68 Id at 538 .

69 Id.

70 Id at 538 n 10, quoting James Wm. Moore, 3B Federal Practice 24.09-1[4] (Matthew Bender 2d ed 1969). 
B. The Circuit Split on Rule 24(b) Permissive Intervention

1. Cases allowing intervention without a showing of Article III standing.

The first set of cases has not required a showing of Article III standing by parties seeking to intervene. In Hodgson $v$ United Mine Workers, ${ }^{71}$ the Court of Appeals for the District of Columbia did not even mention Article III standing when it held: "The right of intervention conferred by Rule 24 implements the basic jurisprudential assumption that the interest of justice is best served when all parties with a real stake in a controversy are afforded an opportunity to be heard." ${ }^{\prime 2}$ In a case decided before the 1966 amendment to Rule $24(\mathrm{a}){ }^{73}$ the same court barely mentioned Article III in allowing intervention. Instead, the court based its reasoning on the view that the intervenors had "such a vital interest in the result of [the] suit that they should be granted permission to intervene as a matter of course unless compelling reasons against such intervention are shown." ${ }^{75}$

In Ruiz $v$ Estelle, ${ }^{76}$ however, the Fifth Circuit extensively discussed Article III standing, permissive intervention, and intervention as of right when determining whether two Texas legislators had the right to intervene in a twenty-five-year-old suit regarding Texas prison conditions. The court assumed arguendo that the legislators would not meet the requirements of standing, but held that "Article III does not require intervenors to independently possess standing where the intervention is into a subsisting and continuing Article III case or controversy and the ultimate relief sought by the intervenors is also being sought by at least one subsisting party with standing to do so." Therefore, even though the Ruiz court assumed that the intervenors did not have Article III standing, it held that they did not need to have Article III standing to intervene in a pending case. In reaching this result, the Fifth Circuit argued that courts requiring intervenors to demonstrate Article III standing had misinterpreted Diamond and "offer little justification" for "this new requirement."

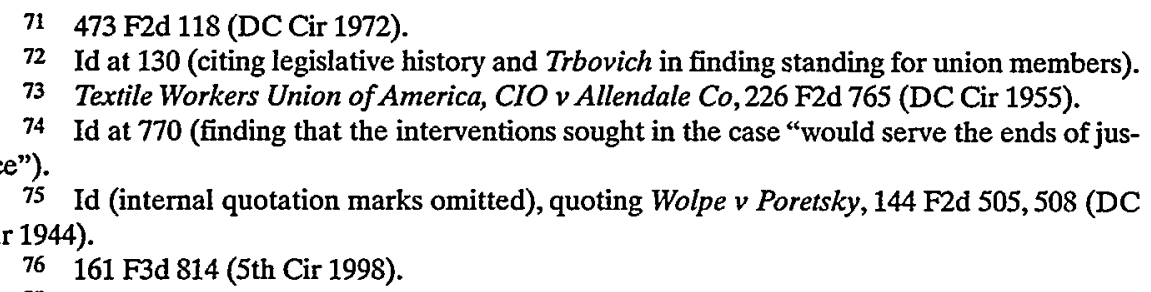


In addressing a factual situation similar to Diamond, the Sixth Circuit in Associated Builders \& Contractors $v$ Perry ${ }^{79}$ refused to allow an intervenor to appeal once one of the original parties had opted not to appeal. The Sixth Circuit reasoned that the failure of an original party to appeal meant that there was no longer a case or controversy for the purposes of Article III. ${ }^{\text {so }}$ The court, while denying standing based on facts distinguishable from situations in which an intervenor is merely trying to have her voice heard in a case on the trial court level, cited Trbovich for the proposition that standing requirements are not the same for parties seeking to intervene and parties seeking to bring the suit originally. ${ }^{81}$

In Chiles $v$ Thornburgh, ${ }^{82}$ the Eleventh Circuit addressed various types of standing, including standing for counties, states, homeowners, detainees, and a United States senator to sue the federal government. ${ }^{83}$ In its discussion of intervenors, the court held that "a party seeking to intervene need not demonstrate that he has standing in addition to meeting the requirements of Rule 24 as long as there exists a justiciable case and controversy between the parties already in the lawsuit."

Importantly, the court went on to state: "The standing cases, however, are relevant to help define the type of interest that the intervenor must assert." quiry in Chiles, which bore striking similarities to the Article III standing analysis. The court found in part that the governor of Florida, suing on behalf of his state, did not have standing because the injury he asserted was not suffered by the state as a whole. ${ }^{86}$ In addition, in finding standing for Dade County to intervene, the court stated, "There can be no doubt that Dade County has standing under Article III.... Moreover, it is reasonable to assume that the injury will be redressed by a favorable judicial decision., ${ }^{, 77}$ When even a court that has stated that the Article III standing inquiry is not required still finds it necessary to engage in such an inquiry, the necessity of adopting a clear rule becomes even more obvious.

7916 F3d 688 (6th Cir 1994).

80 Id at 692.

81 Id at 690 .

82865 F2d 1197 (11th Cir 1989). Chiles is the case upon which the opening hypothetical is based. See text accompanying notes $1-5$.

83 Senator Chiles was the only party originally suing the Attorney General-the other parties all sought to intervene.

84 Chiles, $865 \mathrm{~F} 2 \mathrm{~d}$ at 1213.

85 Id.

86 Id at 1209.

87 Id. 
2. Cases holding that Article III standing is a lower hurdle than the intervention requirements of Rule 24(b).

In a second group of cases, courts held that Article III standing is a lower hurdle than Rule 24's requirements for intervenors. Therefore, the courts reason, although intervenors should meet Article III's requirements, permissive intervenors do so by meeting the requirements of Rule 24(b). While Article III would appear not to prevent intervention under this approach, this test does not fully solve the problems that result from applying Article III to intervenors because the courts taking this view proceed to analyze the Article III requirements.

United States $v 36.96$ Acres of Land $d^{3 s}$ is somewhat constructive, though it deals primarily with intervention as of right. In that case, the Seventh Circuit held that " $[t]$ he interest of a proposed intervenor ... must be greater than the interest sufficient to satisfy the standing requirement." This statement was based on differentiating between an interest sufficient for standing and the "direct, significant, legally protectable interest" required for intervention. Judge Cudahy's dissent, however, rebuts the majority's holding by arguing that requirements for intervention should be more liberal than those for standing to sue. In. particular, Cudahy relied upon a 1972 Seventh Circuit opinion, United States $v$ Board of School Commissioners," for the proposition that requirements for intervention should be more liberal than those for standing to sue. Judge Cudahy referred to the majority's reasoning as "highly formalistic" and "sterile" and cited numerous authorities for the proposition that "traditional standing is sufficient interest to intervene where denial of intervention will prevent appellate review.",

In United States Postal Service v Brennan, the Second Circuit found that the would-be intervenor at issue was not entitled to intervene as a matter of right and that the district court had not abused its discretion in denying permissive intervention under Rule 24(b)(2). ${ }^{n}$ The court stated, however, "The existence of a case or controversy having been established as between the Postal Service and the Bren-

88754 F2d 855 (7th Cir 1985).

89 Id at 859 .

90 Id.

91466 F2d 573 (7th Cir 1972).

9236.96 Acres of Land, $754 \mathrm{~F} 2 \mathrm{~d}$ at 861 (Cudahy dissenting).

93 Id.

94 Id.

95 Id, citing Moore, 3B Federal Practice $\$ 24.07$ [2] at 24-48 (cited in note 70); United States v Imperial Irrigation District, 559 F2d 509 (9th Cir 1977); Bryant v Yellen, 447 US 352, 366-68 (1980).

$96 \quad 579$ F2d 188 (2d Cir 1978).

97 Id at 190. 
nans, there was no need to impose the standing requirement upon the proposed intervenor." ${ }^{198}$ While that view would appear to favor wouldbe intervenors, the fact that the trial court's denial of intervention was upheld highlights the importance of a clear standard for trial courts to follow, given the difficulty of fixing an erroneous denial of permissive intervention at the appellate court level.

3. Cases holding that intervenors must meet Article III's requirements.

A third group of cases holds that would-be intervenors must meet the requirements for Article III standing. These cases have relied upon either a jurisdictional or an "equal footing" argument. The most illuminating case in the jurisdictional category is Mausolf $v$ Babbitt, ${ }^{\circ 9}$ in which a divided Eighth Circuit panel held that intervenors must meet the Article III standing requirements. The court reasoned that intervenors seek to participate in lawsuits and ask courts to decide the merits of their claims, so if intervenors do not possess standing, then their participation threatens to destroy the court's jurisdiction over the case. Basing its holding on jurisdictional grounds, the majority stated that "an Article III case or controversy, once joined by intervenors who lack standing, is-put bluntly-no longer an Article III case or controversy.",

Other cases in this category have not relied on the jurisdictional view advocated by the Eighth Circuit. The Seventh Circuit and D.C. Circuit have adopted the "equal footing" argument. Under this analysis, because an intervenor is thought to have the same rights and thus be on equal footing with the original parties in the suit, intervenors must meet the same standing requirements as the original parties to the suit. ${ }^{101}$ The problem with the equal footing argument is that it rests

98 Id

9985 F3d 1295 (8th Cir 1996).

100 Id at 1300 . An earlier case reaching the same result, but of more limited usefulness, is Southern Christian Leadership Conference v Kelley, 747 F2d 777 (DC Cir 1984). The analysis in Kelley is not very helpful because, as the Fifth Circuit has commented, the opinion "merely assumes that Article III requires intervenors to possess standing and offers neither precedent nor reasons to support this assertion." Ruiz, $161 \mathrm{F3d}$ at 831 . In fairness, however, the Kelley opinion dispenses with Article III issues in such short order because the case involved numerous other standing-related issues which allowed the court to dispense with the case based on several other grounds, such as standing for Senator Helms as an individual Senator and standing for Senator Helms on behalf of the Senate (when the Senate's intent appeared to contradict a grant of standing). See Kelley, 747 F2d at 781.

101 Cases using this logic include Solid Waste Agency of Northern Cook County $v$ United States Army Corps of Engineers, 101 F3d 503, 507 (7th Cir 1996) ("The threatened injury [destruction of a property right] would give him [the hypothetical party] the minimal standing required by Article III, which our court requires of any intervenor."); City of Cleveland v Nuclear Regulatory Commission, 17 F3d 1515, 1517 (DC Cir 1994) (stating that because a Rule 24 inter- 
on the premise that intervenors are equal to other parties. However, both Diamond ${ }^{102}$ and the Seventh Circuit's analysis in Solid Waste Agency of Northern Cook County v United States Army Corps of Engineers ${ }^{103}$ indicate that such a premise is false because of the importance of having original parties involved in the appeal.

In Diamond, the original parties opted not to appeal, and the Supreme Court dismissed the intervenor's appeal for want of jurisdiction. ${ }^{104}$ Thus, an intervenor must hope that an original party appeals, because the intervenor cannot do so itself. Arguing that a party dependent on original parties is on equal footing with those original parties who are free to appeal regardless of the intervenor's decision clearly does not make sense. As the Solid Waste Agency opinion recognized, "[t]he strongest case for intervention is not where the aspirant for intervention could file an independent suit, but where the intervenor-aspirant has no claim against the defendant yet a legally protected interest that could be impaired by the suit."105 While there may be sound arguments in favor of requiring that permissive intervenors meet Article III standing requirements, the equal footing argument does not appear to be one of them.

\section{Problems Resulting from the Current Case Law}

Due to the circuit split and confusion over the requirements for intervenors, the situation referred to in the opening hypothetical has come to pass: one's right to intervene is dependent not upon the Federal Rules of Civil Procedure or the Constitution, but instead upon the circuit in which the suit is brought. This situation not only denies would-be intervenors the right to intervene, but also encourages forum shopping by plaintiffs who anticipate the possibility that a third party will intervene. ${ }^{106}$ These outcomes seem at odds with the Rules themselves, which state that they are to "be construed and administered to secure the just, speedy, and inexpensive determination of

venor seeks to participate on an equal footing with the original parties, he must satisfy the standing requirements imposed on those parties).

102476 US 54 (1986).

103101 F3d 503 (7th Cir 1996).

104 See discussion of Diamond in text accompanying notes 58-62.

105101 F3d at 507, citing David L. Shapiro, Some Thoughts on Intervention before Courts, Agencies, and Arbitrators, 81 Harv L Rev 721, 726-27 (1968).

106 Plaintiffs may even feel that third-party intervention will be in their best interests and will therefore seek an intervention-friendly jurisdiction. For a discussion of the costs and realities of forum shopping, see, for example, Mary Garvey Algero, In Defense of Forum Shopping: A Realistic Look at Selecting a Venue, 78 Neb L Rev 79, 82 (1989) (urging an acceptance of forum shopping, in some cases, "as simply a procedural part of litigation"). See also Michael E. Solimine, The Quiet Revolution in Personal Jurisdiction, 73 Tulane L Rev 1, 55-57 (1998) (arguing that forum shopping is not as pervasive as is often claimed). 
every action. ${ }^{\text {"107 }}$ While disagreements among the circuits are not unusual, a circuit split in an area as fundamental as whether a party's voice can be heard in litigation in which it has an interest ${ }^{108}$ is highly problematic.

In addition, as United States Postal Service v Brennan demonstrates, ${ }^{109}$ the district courts have a great deal of discretion over grants of permissive intervention. Therefore, it is even more critical that the Supreme Court clearly instruct the circuits on what procedure should be followed in determining whether intervenors can join a suit. That standard should allow a party to intervene, so long as (1) the would-be intervenor meets the requirements of Rule 24 and (2) the original parties remain in the suit and satisfy the requirements of Article III standing.

\section{Allowing PERMissive InTERVENTION WHEN THE INTERVENOR SATISFIES RULE 24 AND THE PRIMARY PARTIES SATISFY ARTICLE III}

While it may not always increase the speed of adjudication, the most equitable way to ensure that justice is done in a particular suit is to allow intervention by parties who meet the requirements of Rule 24 even if they fail to meet the standing requirements on their own. This allows relevant voices to be heard, but ensures that the courts will not become unnecessarily clogged.

Although the Constitution established federal courts as courts of limited jurisdiction, it allocates to them jurisdiction over "Cases" and "Controversies." fied by the existence of a case or controversy between the original parties, the intervenor should be allowed to have her interests heard in the suit, particularly because she may have no other remedy. ${ }^{11}$ In

107 FRCP 1. Although it could be argued that a "speedy and inexpensive" determination is best achieved by not allowing some groups to intervene, a would-be intervenor can still attempt to have his own cause heard in a separate action. Thus, the opposing party would still have to spend time and money defending himself in this later suit, or getting the would-be intervenor's claim in a separate suit dismissed for lack of Article III standing, and would not enjoy finality at the end of the original suit.

108 The party must have an interest in the litigation, or it would not have met the Rule 24 requirements. See Part II.A.

109 See note 5 and accompanying text.

110 See note 4.

111 This is often alleged by environmental groups seeking to intervene. The Seventh Circuit's reply to this argument in 36.96 Acres of Land, $754 \mathrm{~F} 2 \mathrm{~d}$ at 859-60, was that parties can seek a writ of mandamus under 28 USC $\$ 1361$ in cases in which they seek to force the government or an agency to perform a duty. The problem with that argument, as the court acknowledged, is that "the remedy of mandamus is a drastic one to be invoked only in extraordinary situations." Id at 860 . While not addressed by the court, an additional problem is that writs of mandamus are inapplicable to many of the suits in which parties are attempting to intervene, such as intervention 
addition to allowing an opportunity to be heard when no other opportunity may exist, allowing an intervenor to participate in a case in which she has a demonstrated interest is consistent with the language of Rule 24(b), the spirit of the Federal Rules, and our Constitution's and political system's emphasis on individual rights and the right to be heard. To refuse intervention is, in some situations, directly contradictory to the notion that an individual should have her day in court and be able to fight on her own behalf. Furthermore, this proposed solution is consistent with Supreme Court language that, if followed by the lower courts, would appear to resolve this issue. As the Court noted in 1940 , the Rule "plainly dispense[s] with any requirement that the intervenor ... have a direct personal or pecuniary interest in the subject of the litigation."

Prudential standing is frequently justified as a way to ensure separation of powers - the courts should not be resolving matters better resolved by other branches of government. ${ }^{113}$ Commentators have noted that courts are more reluctant to find standing independently than in cases where Congress, through statute, has provided the plaintiff either standing or an argument that she is within the zone of interests protected by the statute. ${ }^{114}$ However, the spirit of the Rules suggests that courts should favor allowing permissive intervention. ${ }^{115}$ In addition, the reality is that if Congress wishes to require an Article III showing, it can express that view, either by statutory enactment or by using the political means at its disposal to amend the Rules. ${ }^{116}$

Ideally, the Advisory Committee would adopt an amendment specifying that only the requirements of Rule 24(b) apply to permissive intervenors and that they need not meet Article III's requirements when the original plaintiffs in the case have already established them. But rather than waiting on the Advisory Committee, courts should simply adopt this approach. ${ }^{117}$ This would end the confusion surrounding intervention requirements and ensure that the plight of

in a suit between two private parties over logging rights.

112 SEC v US Realty \& Improvement Co, 310 US 434, 459 (1940).

113 See generally David E. Engdahl, Intrinsic Limits of Congress' Power Regarding the Judicial Branch, 1999 BYU L Rev 75 (discussing the Necessary and Proper Clause as the true premise for most laws regarding the judiciary).

114 Nowak and Rotunda, Constitutional Law $\$ 2.12$ at 77 (cited in note 23).

115 See Part I.B for a discussion of the spirit of the Rules.

116 In particular, Congress could express its preference for another rule by amending 28 USC $\$ 1367$.

117 See Harold S. Lewis, Jr., The Excessive History of Federal Rule 15(c) and Its Lesson for Civil Rules Revision, 85 Mich L Rev 1507, 1508 (1987) (arguing that "the Supreme Court and the Judicial Conference of the United States has [sic] failed to stay abreast of litigation developments that warrant consideration of Rules amendments" and that the Supreme Court "even with its extensive drafting support team, needs assistance in its role as principal promulgator of Federal Rules amendments"). 
the party seeking to intervene is not decided based solely on circuit boundaries, while also allowing Congress to weigh in on the issue, as the Constitution provides. Even a clear statement that Article III requirements do apply to intervenors would be preferable to the circuit split. The optimal solution, though, would not require permissive intervenors to meet Article III standing requirements.

This proposed solution comports with the spirit and language of the Federal Rules generally and Rule 24(b) specifically. As noted above, Rule 24(a) (intervention as of right) was amended in 1966 in such a way to prevent the Rule from "defeat[ing] intervention in some meritorious cases." ${ }^{\text {,18 }}$ Clearly, the Advisory Committee, while not wanting the courts to be overrun with frivolous intervention attempts, did not intend meritorious intervenors to be barred from intervention unnecessarily.

The importance of courts' adoption of the proposed solution is especially great because intervenors frequently lack any political clout and have no other way to protect their rights." If the parties are judged to fail the Article III standing requirements as intervenors, they will almost certainly fail an Article III determination if they were to attempt to bring a separate suit following the original adjudication. Even if the intervenors are able to get into court on their own, they may have difficulty convincing a court to disturb the finality of the judgment in the initial case, meaning they might never be heard in court. This is particularly an issue when the would-be intervenor is not a U.S. senator ${ }^{120}$ or an organization that could potentially organize to have a voice in the political process, but is one individual doctor ${ }^{121}$ or a group of migrant farm workers. ${ }^{12}$ The court system is intended to be a forum in which the voices of all are heard equally, but applying Article III standing requirements to permissive intervenors ensures that some voices are never heard at all.

Beside the point that the inclusion of parties in the judicial determination may increase their support of the judicial system, ${ }^{123}$ the ju(a)).

118 FRCP 24, Advisory Committee's Note to the 1966 Amendments (modifying subdivision

119 Consider, for example, the individual doctor seeking to intervene in Diamond, 476 US at 56 , or the migrant workers in Usery, 87 FRD at 673.

120 This was the case in Chiles, 865 F2d at 1200, and Southern Christian Leadership Conference $v$ Kelley, 747 F2d 777, 778 (DC Cir 1984). For a discussion of Chiles, see notes 82-87 and accompanying text. For a discussion of Kelley, see note 100.

121 This was the case in Diamond, 476 US at 56.

122 This was the case in Usery, 87 FRD at 673.

123 Although some might argue that preserving confidence in the justice system is not a goal with which the courts should be concerned, there are many reasons why the legal profession should care about faith in the justice system. Perhaps the most cynical is that "[w]hen people lose confidence in the justice system, they have little reason to support funding for and the independence of judges." Karen A. Lash, Pauline Gee, and Laurie Zelon, Equal Access to Civil Justice: 
dicial system can benefit directly from the inclusion of intervenors unable to meet Article III's standing requirements. Returning to the original hypothetical, allowing intervention by a homeowner living near the facility being used to house convicted felons would enable the court to hear a perspective that a United States Senator, concerned primarily with the political issue of alleged lies by the Department of Justice, might not have. Allowing intervention in this case, as in many other permissive intervention situations, enables the court to base its decision on more complete information, thus potentially offsetting any increase in decision costs by reducing error costs. This example indicates that, rather than just benefiting intervenors by making them feel included, adopting the proposed solution could benefit the justice system in tangible ways.

Not all parties seeking to intervene are as sympathetic as the migrant workers in Usery $v$ Brandel ${ }^{124}$ or the homeowners in Chiles $v$ Thornburgh. ${ }^{125}$ Some might argue that would-be intervenors should either be able to meet Article III's requirements or use the political process to effectuate their desired result. However, the reality is that if parties are powerful enough to find relief in the political process or able to meet the Article III standing requirements, they may find it more efficient and satisfactory to pursue suits of their own or use political pressure than to intervene in another's suit. While intervenors may include politically powerful groups such as the Sierra Club or paper companies, intervention can also serve as a tool of last resort for groups and individuals lacking political clout or Article III standing.

A potential drawback to the adoption of the proposed solution is increased delays in litigation, which would result in higher litigation costs (both for the parties and the judicial system) and higher administrative costs. In the case of intervenors, however, granting permissive intervention does not risk prolonging a determination indefinitely after the original adjudication because being allowed to intervene does not entitle a party to appeal once the other parties drop out. Rather, this Comment proposes adopting a standard (similar to that in Diamond) under which an intervenor can only appeal once the original parties have dropped out if the intervenor makes an independent showing of Article III standing. ${ }^{126}$ Therefore, allowing intervention

\footnotetext{
Pursuing Solutions beyond the Legal Profession, 17 Yale L \& Pol Rev 489, 500 (1998).

12487 FRD at 673.

$125865 \mathrm{~F} 2 \mathrm{~d}$ at $1201-02$.

126 Although the Court stated in Stringfellow $v$ Concerned Neighbors in Action, 480 US 370 , 375-76 (1987), that "[a]n intervenor, whether by right or by permission, normally has the right to appeal an adverse final judgment by a trial court," the Court held in Diamond, 476 US at 69 , that an intervenor seeking to appeal once the original parties no longer remain in the suit must meet the Article III standing requirements.
} 
without a separate showing of standing is not too great a hindrance to the original parties.

Another concern is that the primary parties to a suit will not be able to have a determination on the issues between them without their case being taken over by intervenors who present themselves as concerned citizens or public interest organizations. Rule 24(b) can be applied to prevent this problem of frivolous intervention. The Rule directs courts to consider "whether the intervention will unduly delay or prejudice the adjudication of the rights of the original parties." ${ }^{127}$ Courts can ensure that the original parties control the direction of their suit by finding that a particular intervenor's claims and interests are "duplicative" and therefore threaten "to unduly delay the adjudication of the rights of the parties in the lawsuit and make[ ] it unlikely that any new light will be shed on the issues to be adjudicated."12s Courts by the same method can frustrate intervenors seeking to take over the litigation or intervenors whose interests technically rise to the level required by Rule 24(b) but who are actually interested only in delaying the case.

In addition, this clear standard of not imposing the requirements of Article III on intervenors meeting the requirements of Rule 24 would limit the problem of forum shopping (either to prevent intervention by intervenors favorable to the defendant or to encourage intervention by intervenors favorable to the plaintiff). Additionally, allowing intervention may in some cases avoid potential litigation after the original suit because all parties have participated and are bound by the suit. Even intervenors who lose on the merits may feel their voices were heard, so that they no longer feel the need to continue battling in court. Therefore, allowing intervention can ultimately save time and resources, as well as preserve faith in the justice system.

\section{CONCLUSION}

The courts should adopt a uniform standard for granting standing for permissive intervention in a suit. That standard should allow a party to intervene, so long as (1) the would-be intervenor meets the requirements of Rule 24 and (2) the original parties remain in the suit and satisfy the requirements for standing. This rule is consistent with the language of Rule 24(b), the history and policy goals of permissive intervention, and the Federal Rules of Civil Procedure. In many cases, the rule would allow voices to be heard in a suit that would otherwise be silenced. Finally, a uniform rule would avoid punishing would-be

127 FRCP 24(b).

128 Chiles, 865 F2d at 1215.

129 See note 123. 
intervenors based solely on where the original plaintiff filed the suit. A consistent rule would also recognize that the importance of allowing intervenors to be heard can be reconciled with the concerns of efficiency and protection of the rights of the original parties as guaranteed by Rule 24(b). Moreover, by adopting the rule proposed in this Comment, courts would recognize that allowing legitimate grievances to be heard is too important to be determined by district court boundaries. 


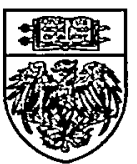

